\title{
Aleš Gabrič \\ Jože Pučnik on a Path to Becoming a Dissident
}

\section{IZVLEČEK}

\section{JOŽE PUČNIK NA POTI DO DISIDENTA}

Primer obračuna $z$ Revijo 57 konec 50-ih let je bil eden najbolj razvpitih sporov slovenskih komunistov $z$ mlajšo generacijo intelektualcev, ki so po drugi svetovni vojni oblikovali svoj svetovni nazor. Jože Pučnik je med somišljeniki, ki so pozornost pritegnili s svojo ostrino, še posebej izstopal. Že med študijem je v svojih člankih v Reviji 57 kritiziral režim. $V$ najbolj spornem članku je analiziral razhajanja med idejami vladajoče elite in realnostjo ter med miselnostjo in delom komunistov dve desetletji prej, ko so delovali nezakonito, in po vojni, ko so se utrdili na oblasti. Konec leta 1958 in v začetku 1959 je bila Revija 57 večkrat tarča kritik vodilnih politikov in tema številnih sej visokih organov. Politiki so neprestano ponavljali, da gre za skupino mlajših intelektualcev, ki da je snovala ilegalno sovražno organizacijo, širila protidržavno propagando in dilasovstvo, pozivala delavce $k$ štrajku itd. Višek obračuna je bilo sojenju Pučniku 30. marca 1959, v katerem je bil obsojen na devet let hude zaporne kazni.

Ključne besede: Jože Pučnik, Revija 57, intelektualci, komunistični režim, Slovenija

\section{ABSTRACT}

The case of settling scores with Revija 57 at the end of 50's is one of the most infamous disputes of the Communist government in Slovenia with a younger generation of intellectuals who had shaped their worldview after WWII. Jože Pučnik stood out among its contributors,

* Research Counsellor, PhD, Institute of Contemporary History, Kongresni trg 1, SI-1000 Ljubljana, Slovenia, ales. gabric@inz.si 
who attracted attention with the sharpness of mind. The criticism of the regime was during his study reflected in Pučnik's articles in the Revija 57 magazine. In the most controversial article Pučnik analysed the discrepancies between the ideas of the ruling elite and reality, and between the mentality and the work of the Communists two decades earlier, when they were still operating illegally, and after the war, when they consolidated their official power. At the end of 1958 and in early 1959, the Revija 57 magazine was repeatedly targeted by the leading politicians and became the subject of numerous sessions held by high-level authorities. The politicians reiterated that the magazine were a group of young intellectuals, who formed an illegal hostile organization, spread anti-state propaganda and djilasism, called on workers to go on strikes etc. The encounters and intimidations finally escalated in a trial held on 30 March 1959, in which Jože Pučnik was sentenced to nine years of severe imprisonment.

Key words: Jože Pučnik, Revija 57, intellectuals, communist regime, Slovenia

\section{Contributor to the Revija 57 Magazine with a Police Record}

The case of settling scores with Revija 57 is one of the most infamous disputes of the Communist regime with a younger generation of intellectuals who had shaped their world view after WWII. Jože Pučnik stood out among its contributors, who attracted attention with the sharpness of mind. His life experience distinguished him from most of the magazine's associates, as he had already experienced close encounters with the state security. As a grammar school student, he demonstrated the political aspect of his work when, due to disagreement with actions taken by the youth organization, he left the organisation and started publishing the Iskanja bulletin with a few of his friends. Iskanja was mostly a literary newspaper published by students without official permission and with articles written under pseudonyms. The unnamed author of the first issue editorial published in January 1951 was Jože Pučnik. This was confirmed decades later, when he said: "I'm still proud of being the first person to write an introductory article, a sort of a programme that was to a certain extent, oppositional and, of course, slightly romantic." ${ }^{1}$

In fact, said editorial published in Iskanja stands out due to its sharpness of thought. A few years after the war, it was not normal for someone to write about the fact that the psyche of "today's man is chained in the shackles of legitimised violence". "The autocrat is trying to destroy the close ties among people," wrote the editor, and the reader could only smile at the thought of who this autocrat could be. "Plain speech is banned," was the motto of the editor, which was followed by a deliberation on fear and courage in the hearts of the people, all this just a year and a half before these exact two words,

1 Janko Lorenci, Jože Pučnik (Ljubljana: Emonica, 1990), 24. 
which appeared in the title of Edvard Kocbek's collection of novellas, insulted those in authority. In his outline of the situation at the time, Pučnik highlighted the violence of the government in the form of icy concrete of solitary confinement units, violent hands, "empty words accompanied by a hypocritical smile", and a "tense barbed wire resting on bloody bayonets" encircling it all. In order to overcome all of these issues, the editorial called for poetry and openness, so "that we would release from his violent numbness the healthy vital force and with it a decisive requirement for a free, open and beautiful word".

\section{A Socially Engaged Student}

Pučnik then had to leave grammar school with several other colleagues and was forbidden to attend final exams. However, the punishment was subsequently reduced, and after returning from military service and completing secondary education, Pučnik enrolled as a student at the Department of Philosophy of the Faculty of Arts in Ljubljana. ${ }^{3}$ He was active in the Students' Union (Zveza študentov) and in debates that brought him closer to the circle of the Revija 57 magazine. He wrote several articles for a newspaper about the state of affairs in the society in Yugoslavia at the time. Although Pučnik was no different than others in voicing criticism, his words were usually very direct and easy to understand, while the articles of some other writers had to be read between the lines. He also differed from the central circle of the Revija 57 magazine due to the social class from which he originated. While other rebels mostly originated from the bourgeoisie, from financially well-established backgrounds, which was especially the case with children of political officials, he came from a farming environment and was able to witness the poverty of the farming class from up close. He also differed by the fact that he had already faced the work of the police, although the thought of having to encounter police was also not foreign to many of his contemporaries. Janko Kos, for example, heard after his controversial discussions with Ziherl that it was allegedly discussed at party meetings whether or not to imprison him, but he was taken under the wing by two intellectuals from the upper political circles, Ferdo Kozak and Josip Vidmar. ${ }^{4}$ In early 1958, Pučnik's social engagement also led him to join the League of Communists of Slovenia, a move which elicited extremely controversial responses. When he informed his colleagues of this decision, he had a sense that "they would beat me up", while Primož Kozak asked him in private whether he was a police agent. ${ }^{5}$

The decision to join the political party in power provoked such unusual responses among his colleagues because it contradicted everything they thought and fought for. Their articles and conversations had a political note and criticised the system, opposed

2 Author's archives Iskanja, No. 1, January 1951, 1, 2. A copy of the newspaper was sent to me by the son of Jože Pučnik, Gorazd Pučnik, for which I would herewith like to extend my sincere gratitude.

3 SI AS 1931, t. e. 1146, 217, 218, 1, 2.

4 Janko Kos, Umetniki in meščani: spominjanja (Ljubljana: Beletrina, 2015), 166.

5 Lorenci, Jože Pučnik, 24. 
the values of the government, and, to an extent, also the value system of their parents, as children of politicians were also in their ranks. The criticism of the regime was also reflected in Pučnik's articles in the Revija 57 magazine. In an article titled The Moral Roots of the Personality Cult from 1957, he devoted himself to this phenomenon in the Soviet Union, but clearly wrote among other things: "The problem of the personality cult is a general social problem in socialist systems and is not related only to Stalinism or the Eastern bloc." ${ }^{6}$ In the article The Society and the State from the same year, he touched upon the relationship of the individual with the society at large and advocated the rights of the individual because "the liberation of a person is a release from everything that is above and beyond them, be it God, a monarch or a state". In an article titled Towards Freedom, Pučnik emphasized the European tradition of values, embedded Karl Marx into it, and concluded with a reflection on freedom within the specific reality in Yugoslavia. Although he emphasized that, after the political revolution, there was a time to consolidate the new legal system, he also warned as follows: "The legal and political changes brought about by the new system are in themselves insufficient." The rights were all too often left at a formal level and could not be exercised by individuals in their actual lives. Values in Yugoslavia, stressed Pučnik, have a long way to go before they will be transformed from theory to reality. ${ }^{8}$

In several articles, Pučnik argued that the state should be built to suit the people and not in a way so as to demand that people to personally submit themselves to the will of the state. Although Pučnik made no references to Tito in the outline of the personality cult, and although he did not point out that a different principle was in place in Yugoslavia when emphasizing the rights of the individual in relation to the state, it was clear to readers that his ideas were not only about general problems, but about problems that people faced at home at every step. Pučnik's articles reveal a person whose views on social issues were quite different from those of the government and who also openly advocated these principles in public.

The leadership of the League of Communists of Slovenia discussed the issues raised by Revija 57 more seriously for the first time at the meeting of the ideological committee on 26 November 1957. The rise of criticism at Revija 57 was evident by the mere fact that, in the case of its predecessor, a magazine called Beseda, communist ideologists only attacked its ideological premises, while in the case of Revija 57, they also talked about the integration of informal groups that could, in the future, create a political opposition block. The Revija 57 team was accused of being a part of the younger generation which had not yet comprehended the great changes occurring in the society after 1945 and which lacked criticism when assessing the western society. From this point of view, Revija 57, according to the party leaders, had an overly strong influence on the students of the Faculty of Arts. Ideologists found the power of the Revija 57 circle at the humanities departments especially dangerous, as it hindered 
the League of Communists of Slovenia in its planned transformation of the university according its own taste and its indirect (ideological) influence on the future generations of intellectuals. ${ }^{9}$ The government was able to exercise more political pressure on Revija 57 than on the Beseda magazine because the former had, in accordance with the provisions of the Act on Publishing, a formal publisher. However, the Yugoslavian Federation of Students in Ljubljana did not utilise this power, as publisher Janez Vrhunc, according to those in power, did not play his role, since he did not prevent the publication of any article that the ideologists assessed as controversial or inadequate. The University Committee of the League of Communists therefore dismissed Janez Vrhunc and in March 1958 appointed in his place Rado Jan, the secretary of the basic organization of the League of Communists at the Faculty of Arts. ${ }^{10}$

Those working for the Revija 57 magazine were aware of the political connotations of their work. Pučnik mentioned that he and the circle of colleagues, including Janko Kos, Taras Kermauner, Veljko Rus, Primož Kozak and others, held "many political discussions." ${ }^{11}$ One such conversation, which carried on long into the night, took place in the summer of 1958 at Primož Kozak's home. There, it was agreed that everybody of them would write contributions on the social and political reality of the time. However, one should not ignore a fact that those describing Pučnik's work have so far not emphasised. The agreement among the young intellectuals came to an end shortly after the seventh Congress of the League of Communists of Yugoslavia in Ljubljana in April 1958. Party ideologists saw the event as a turning point because of the new programme of the League of Communists of Yugoslavia that was adopted there. On the one hand, the programme offered some novelties introduced into socialism by Yugoslavian communists after the dispute between Yugoslavia and the Soviet Union a decade earlier, but on the other hand, the ruling party's announcement was about the manner in which the society and the state would be developed in the following period. The programme was written at a time of newly aggravated relations with the Soviet Union and in light of the discontent shown by other communist countries. The Congress was important for the internal political scene because it was the first time that the topic of relations between Yugoslav nations was addressed at such a high-level event. They added to the traditional political opponents those who allegedly advocated fake liberalism and, by defending the rights of the individual, actually spread anarchism. Attempts to leverage the artistic and scientific sphere in the name of freedom in order to promote anti-socialist ideas were also met with contempt. ${ }^{12}$

In such circumstances, any criticism directed at the party and the state (and, indirectly, at the new programme of the ruling political party) was even less welcome than usual. What is more, such criticism fit neither the Yugoslavian government, which was

9 Aleš Gabrič, Socialistična kulturna revolucija: slovenska kulturna politika 1953 - 1962 (Ljubljana: Cankarjeva založba, 1995), 269-71.

10 Mateja Režek, “Ideološko ozadje ukinitve Revije 57.” Nova revija 13, No. 151/152 (1994), 196.

11 Lorenci, Jože Pučnik, 26.

12 Mateja Režek, Med resničnostjo in iluzijo: slovenska in jugoslovanska politika $v$ desetletju po sporu $z$ Informbirojem: (1948-1958) (Ljubljana: Modrijan, 2005), 191-202. 
afraid that other countries might utilise it as evidence that citizens were dissatisfied with the state, nor the Slovenian authorities, which, in the period of intensified interethnic relations, wanted to have Slovenian intellectuals as allies rather than critics of state policies.

An agreement by the Revija 57 authors to write and publish contributions on the current social situation was therefore made in the wake of unfavourable political conditions. Only Jože Pučnik, who was the only one to put his views on paper, fulfilled the commitment made to his friends to write articles on the social situation at the time. He already had a good draft in his drawer because he had written an article about the party for the Naši razgledi magazine, which he had sent to the members of the editorial board to read. Pučnik was received by Vlado Vodopivec, the then Secretary of State for Culture and Education, and, according to Pučnik, Vodopivec said something like this: "This article is interesting because you are right. But we are approaching a new phase of Stalinism. Please remove this article, we cannot publish it. This is what I wanted to say to you in a friendly manner." After speaking to his friends, Pučnik rewrote the article and offered it to Revija 57 to be published, but even the magazine had reservations about whether to publish such a sharp text. Ultimately, the majority decided to publish it, and the representative of the magazine's founder in the editorial board, Rado Jan, assumed a behind-the-scenes censorship role and prevented the publication of the article. Pučnik initially responded by saying that, in accordance with the old tradition, they should publish some empty white pages in order to make it clear to the readers that the authorities prevented the publication of some of the material confirmed by editors. ${ }^{13}$

In a controversial article titled Our Social Reality and Our Illusions, ${ }^{14}$ Pučnik analysed the discrepancies between the ideas of the ruling elite and reality, and between the mentality and the work of the Communists two decades earlier, when they were still operating illegally, and after the war, when they consolidated their official power. According to Pučnik, after the Communist Party came to power, it suffered a severe crisis from which it could not recover, since on the one hand, it formally wanted to be nothing more but society's ideological leader, but on the other hand, it completely merged with the government in real life. Although the government relied on the rule of the people, the split between its ideology and the people was growing deeper, wrote Pučnik, and asked the question: "It goes without saying that much of the blame for such a social atmosphere in Slovenia rests with the Party and autocratic forums and their antagonistic understanding of society. Distrust and extreme tension, their constant sense of the 'people's power' being in jeopardy, and suspicious speculations about the constant presence of 'enemies to our socialist social system' have now become chronic. One often asks themselves: Do these people have even the slightest sense that they live among their own people and in a state community in which they also are the holders of power?"15

13 Lorenci, Jože Pučnik, 27.

14 SI AS 1931, t. e. 1146, 217, 218, 64-73. Pučnik, Članki in spomini, 50-70.

15 Pučnik, Članki in spomini, 69. 


\section{The Government Exercises Power over Revija 57}

Albeit Pučnik's article was by no means a real cause for the government's actions, the authorities used said article as a reason for exerting pressure on a group of young intellectuals. In July 1958, the editorial board of Revija 57 was notified that the Secretariat for Culture and Education of Slovenia proposed the removal of their subsidy, so in the next few months the Board repeatedly appealed to the competent state body, either through personal contacts or in writing, to prevent this. ${ }^{16}$ However, it was not successful, since an official proposal presented in September 1958 by the Fund for the Promotion of the Publishing Activity at the Council of Culture and Education of Slovenia, listed Revija 57 among those magazines the subsidies of which were to be withdrawn. The Council of Culture and Education of Slovenia rejected the proposal after a stormy debate. However, the Council supported the proposal of its own President, Boris Kocijančič, to keep subsidizing the magazine until the end of the year, when "both the magazine and the Students' Union would have to seriously reconsider the criteria which led the commission to make a proposal to withdraw the subsidy". This was why Revija 57 could not "count on a subsidy in the coming year if the ideas discussed in the magazine deviated from our cultural policy". ${ }^{17}$ The editorial board of the Revija 57 magazine was thus threatened to no longer publish politically undesired articles, otherwise they would lose the subsidy at the end of 1958. In the political reality of the time, this would have resulted in a cancellation.

The debate spread to forums which were supposed to oversee Revija 57. On 4 October 1958, the Central Committee of the People's Youth Organisation of Slovenia and the University Committee of the Students' Union met at a joint session. It was deemed that Revija 57 did not deal with real problems of the present time. When a youth organisation official provided the simple fact "that Revija 57, which is the bulletin of the Students' Union, is reaching beyond the university by addressing current issues", ${ }^{18}$ he pointed out either intentionally or unintentionally something that the government feared the most.

In October 1958, only a month before the first proposal was made to cancel Revija 57, the government launched a campaign that led to the magazine's ultimate cancellation. As a formal reason, they cited the sharp criticism of society in issues 5-6 of the second year of the magazine, although similar criticism could also be found in previous issues of the magazine. In the above issue, the first sharp criticism was contained right at the beginning, in the editorial. Namely, the editorial touched on the meeting of the Council for Culture and Education of the Slovenian People's Republic and the proposal to withdraw its subsidy for Revija 57. At the end of the magazine, two articles were published discussing the anniversary of the closing of the Prešeren Theatre in Kranj and the resulting negative consequences as well as criticism directed

16 Vital Klabus, “Pričevanje o Reviji 57 in Perspektivah.” Borec 48, No. 551/552 (1996), 113, 114.

17 Režek, Ideološko ozadje ukinitve Revije 57, 198, 199.

18 SI AS 1799, t. e. 83, Zapisnik seje predsedstva CK LMS in uni. odbora ZŠJ, 4 October 1958, 7. 
at publishers who, due to their beliefs, refused to accepted a poetry collection by Dane Zajc into their programme. ${ }^{19}$

Jože Pučnik's Our Social Reality and our Illusions, which was just one of the many disruptive articles, but also the most controversial, was deemed by Boris Ziherl as "djilasovskian". Before it was even printed, the article was given to Ziherl to read by "a representative of the Students' Union in this editorial board”, i.e. Rado Jan, who asked Ziherl "what to do with this article". Ziherl replied: "You are the representative of the Students' Union in this editorial board and if you have given veto to the board, then you have the right to appeal to the person who sent you to this editorial board, that is to the Students' Union, to decide in this matter." Ziherl reported to the leading politicians that "this is exactly what happened and the Board of Student's Union rejected the publication of this article". However, because the editorial board threatened to publish an empty page in place of the censored article, "the representative of the Students' Union again came to me for advice on what to do" ${ }^{20}$

In October 1958, police investigators launched an investigation against Revija 57. The confiscation proposal no. 5-6 was just the beginning, as it soon became apparent that after the issue that had already been prepared for printing was confiscated at the Kočevje printing house on 31 October 1958, the government authorities would go even further. The publication of the controversial contribution was by no means a sufficient reason for a wider police campaign, since the publication of the article had already been blocked by the representative of the Students' Union. Far more had to be done for a more extensive campaign; the campaigns undertaken a decade earlier had been a sign that it would be best for intimidation purposes and for the judicial process as such to focus the investigation on proving the attempts to organize an anti-state political organization. The main target of the investigation was Jože Pučnik, who was arrested on the same day as the magazine issue was seized. House searches were carried out at Pučnik's home and the homes of some of his colleagues, several people from the magazine circles were brought in for questioning, and the Revija 57 archives were seized from the editor Vital Klabus. Editors Veno Taufer and Vital Klabus complained to the interior affairs bodies and county authorities of the Socialist Alliance of the Working People of Ljubljana, which, however, did not affect the decisions made by the government authorities at the highest level. This marked the beginning of long-term interrogations for Pučnik and, at least initially, it was not entirely clear to him what the authorities wanted from him. He did not want to discuss the views of his friends and, during discussions about his contributions, he disagreed with the comments of the investigators who considered these views as calls to anti-government actions. ${ }^{21}$

Because the editors did not yield to political demands and did not agree to withdraw certain articles, on 5 November 1958 the Ljubljana District Court complied

19 SI AS 1589, IK, t. e. 12, Revija 57.

20 SI AS 537, t. e. 27, Seja predsedstva SZDLS, 6 November, 1958, 47, 48.

21 SI AS 2027, t. e. 14, Dopis uredništva Revije 57, 2 November, 1958. SI AS 1589, IK, t. e. 12, Revija 57 in Naši nadaljnji ukrepi in rezultati preiskave proti skupini Revija 57. Rosvita Pesek, Pučnik (Celovec: Mohorjeva, 2013), 79-89. 
with the request of the public prosecutor and confiscated the magazine. ${ }^{22}$ The political fate of the magazine and its authors was decided on the following day, on 6 November 1958, at the session of the Presidency of the Socialist Alliance of Working People of Slovenia. Through the following questions, its members indicated the future confrontation with the Revija 57 magazine: How can the writers of such articles be working as teaching assistants at the university?; Why is such a magazine receiving a subsidy?; Is it an organized campaign to provoke the dissatisfied into a revolt?; It is not true that there are too few magazines because don't young people have the Mlada pota magazine? ${ }^{23}$

In mid-November 1958, the state security directed the investigation against the (imaginary) illegal organization, which was allegedly founded by Jože Pučnik. After interrogating those working for the magazine, it was established that most of the editorial board agreed with the publication of contributions deemed by the police as "hostile propaganda", namely they agreed that they were preparing the founding of the Založba 1551 publishing house, where they would also publish works by such writers as Sartre, and that they planned to expand the editorial board with "negative elements", such as Lojze Kovačič and Janko Kos. According to a report of the Internal Administration, young intellectuals felt "that the measures are a staged and a non-serious matter which intends to cause anxiety among them, and they must not fall for it". The fact that the magazine was also defended by some prominent cultural workers of the older generation was also seen as a problem. Among them, the Internal Administration first mentioned Josip Vidmar. Vladimir Kralj allegedly said that the affair was triggered by the "anti-cultural people from Kranjska [central part of Slovenia], who will, however, have to quit at the request of Belgrade", while praises for young people also came from the Catholic intellectual circles, i.e. from Anton Vodnik and Edvard Kocbek. ${ }^{24}$

Jože Pučnik also counted on the possibility that the matter could calm down quite quickly, but he did not know what was happening outside the prison walls. It was not until mid-November, when he was informed that the investigation had been extended pursuant to Article 117 of the Penal Code, which sanctioned illegal association against the state system, that it became clear to him that a nasty confrontation was in sight. Pučnik's activities in the framework of the legally functioning Students' Union and clubs at the Faculty started to be categorised as calls to organise. His involvement was seen only as hiding behind an external façade with the interest of spreading his own anti-state ideas. They began to take the words which he wrote in his articles or spoke at forums out of context, especially those that government officials found the most alarming. The word organization invoked fear, because it could imply that anyone else, not just the leaders in the ruling political parties, were able to discuss political matters in the country. Less than a year after the first major workers' strike in socialist Yugoslavia broke out in Trbovlje, government officials found that a mere reference to

24 SI AS 1589, IK, t. e. 12, Naši nadaljnji ukrepi in rezultati preiskave proti skupini Revije 57. 
the word strike was almost equal to a declaration of war. Six months after the League of Communists adopted the best political programme, the leading Communists found any debate on the Constitution or the political system utterly outrageous. For Jože Pučnik, it was hard to comprehend what was he being accused of: "I do not know, for a long time I did not understand what they really wanted. They accused me of setting up an illegal organization, but I felt that they were not convinced about it either."25

The indications that the police authorities highlighted in their reports for the top government circles in November 1958 were presented by the leading Slovenian Communists in a redacted form at the plenum of the League of Communists of Slovenia on 5 December 1958. They announced a strong response to the activity of those intellectuals of the younger generation who allegedly acted contrary to the interests of the state. Boris Ziherl spoke about ideological political issues, and although he did not name his opponents, he referred a few times to Revija 57, thereby directing his criticism at those who allegedly had too much influence on young people. ${ }^{26} \mathrm{An}$ explanation of the situation concerning the Revija 57 magazine was given in greater detail by Janez Vipotnik. With regard to Jože Pučnik, he found that he was accepted into the League of Communists too quickly and without sufficient consideration. The information that, at the time, "Pučnik was incarcerated due to his anti-state activities"27 was stated by Ziherl as a simple fact which was not to be questioned. With regard to the 40 people who were considered to be a part of the magazine's circle, he found that they wanted to "address social problems from the perspective of intellectuals who were oriented towards non-class division" and that they were not completely on the same page in terms of their convictions. The employees of Revija 57 allegedly committed a serious political violation because "the group wanted to have a literary evening after the strike in Trbovlje, where they wanted to express solidarity with the phenomenon in Trbovlje in a political manner". Vipotnik described the magazine's circle using a distinctly political vocabulary and a very negative connotation. Vipotnik tried to prove that Revija 57 did not have a significant impact on the generation of students, which raised doubts about why the League of Communists of Slovenia was so involved in and why it took on a phenomenon that was supposed to be so marginal. ${ }^{28}$

In December 1958 and in early 1959, the Revija 57 magazine was repeatedly targeted by the leading politicians and became the subject of numerous sessions held by high-level authorities. The politicians reiterated that the magazine were a group of young intellectuals who formed an illegal hostile organization, spread anti-state propaganda and djilasism, called on workers to go on strikes etc. The process was accompanied by strong media campaigns, but the opposing side did not get a chance to defend itself. The interrogations continued, and the two editors, Klabus and Taufer, as well as Taras Kermauner were each sentenced to ten days in prison. The encounters

25 Lorenci, Jože Pučnik, 27.

26 SI AS 1589, IK, t. e. 7, Stenografski zapisnik IX. plenarne seje CK ZKS, 5 December, 1958, $2-13$.

27 Ibid., 32.

28 Ibid., 32-36. 
and intimidations finally escalated in a trial held on 30 March 1959, in which Jože Pučnik was sentenced to nine years of severe imprisonment. ${ }^{29}$

\section{Finding Causes for a Strict Confrontation with Revija 57 and Pučnik}

In the judgment against Jože Pučnik, the court summarized the positions which had been served by the investigators. In a very unconvincing explanation, the court confirmed that there had been an attempt to set up an illegal organization, which allegedly intended to unconstitutionally overthrow the government. By referring to the article Our Social Reality and our Illusions, they attempted to prove the hostile propaganda and the defendant's negative attitude towards the social reality. ${ }^{30}$ After the trial, Pučnik's friends congratulated him for his strong posture; however, this triggered additional measures inflicted by the government authorities.

Subsequent assessments of the judicial confrontation with Jože Pučnik vary, but there is little doubt about some common highlighted points, i.e. that the trial was a judicial construct and an attempt to intimidate the young generation of intellectuals and that the imposed sentence was disproportionately high even by the then case-law criteria. Some also emphasize the fact that Pučnik was the only one without a strong bourgeois and political support base, and therefore, in the company of friends who had fathers in prominent positions, he served as an example to everyone else of what might have happened had they continued along this path. However, by overly limiting the issue to the influence exerted by important fathers, one can easily miss some important emphases. As has already been pointed out, the communist government saw the group related to the Revija 57 magazine, contrary to its predecessor, the Beseda magazine, as very political. However, members of the young generation of intellectuals did not see themselves in the role of (political) opposition at that time. Especially not Jože Pučnik, who had been, after all, a member of the League of Communists of Slovenia until his arrest and who, through legal forms of action, had tried to express what the party should correct if it wanted to act as a workers' avant-garde. Unlike those who are too quick to label themselves using terms such as opposition, dissidence, or a dissident in describing their own past, Peter Božič's assessment was based on contemplation and analysis, which attempted to logically embed the concept of the term opposition into the context of overall events. Božič saw the arrival of Pučnik to Revija 57 as a turning point after which the debate spread from only being in the cultural sphere to integrating cultural and social notions by placing them "into a realistic social space opposite the official one, which was still marked with the ideology of the PARTY". Therefore, according to Božič, Pučnik's role was marked "with the different content framework

29 SI AS 1589, III, t. e. 68, Informacije, No. 49, 11 March 1959, 6, No. 57, 9 April 1959, 10 and No. 59, 18 April, 1959, 4. Klabus, "Pričevanje o Reviji 57 in Perspektivah," 116, 117.

30 Lorenci, Jože Pučnik, 68-74. 
of Revija 57 alone, and thus the first alternative to the party programme as well as the opposition were also de facto created" ${ }^{31}$

However, a participant in numerous discussions of this generation, Janko Kos, pointed out that there must be, nevertheless, a longer journey from criticising the government and drawing ideas that were in glaring contradiction with the party programme to developing a comprehensive alternative programme: "Can I gather some kind of a new ideology from all of this - a political, social and cultural ideology that could be set against the party doctrine? I doubt it, simply because no one has ever formulated it in any obvious way." ${ }^{2}$ In the title of Kos' book describing the events, he used the term disputants for the group to which he belonged. The notion of disputing was best used by Jure Ramšak in his doctoral thesis in which he analysed social criticism in Slovenia during a somewhat later period, i.e. the 1970 s. $^{33}$

The protagonists from the Revija 57 magazine are unanimous in assessing that Jože Pučnik was a step ahead of others, and that he, in addition to writing, acting as an organizer of talks, clubs, seminars, and activities in the framework of legal forums, the League of Communists, and the Students' Union, also performed purely (political) organizational work. However, regarding assessments of whether this was politics or, more precisely, political opposition, opinions differ, even to the point of arguing that the entry into the real political scene can only be placed in the 1980 s and the $57^{\text {th }}$ issue of the Nova revija magazine, and that before that, there were only conceptual fragments that were not yet political enough in the area of activities by magazines that mostly dealt with culture. ${ }^{34}$

The other side, i.e. the top of the ruling League of Communists of Slovenia, was much more uniform in its assessments of Revija 57. The word opposition was expelled from publicly used political vocabulary, but it was used several times when the narrow circles of the highest political authorities discussed their actual and alleged opponents. In the 1950s, high-level political circles were more or less clear that they no longer had to fear the pre-war generation of politicians. This applies both to those who, after the experience of the early post-war years, became passive, and those who experienced communist prison. Although the police monitored potential opponents of the government for many years, officers of the State Security Administration (UDBA) kept getting an increasing number of reports on how various older-generation politicians continued to meet with old political figures, but that these were merely meetings with drinking buddies to comment current events. People who faced the repressive measures of the post-war government were even worse off, as they had to face everyday existential problems after their release from prison. The decreasing need for controlling the older generation of regime opponents started to divert the attention of the police and politicians to the younger critics of the government.

31 Peter Božič, “Moja prva srečanja s Pučnikom,” in: Lorenci, Jože Pučnik, 89.

32 Janko Kos, Ideologi in oporečniki: spominjanja (Ljubljana: Znanstvena založba Filozofske fakultete; Beletrina, 2015), 85.

33 Jure Ramšak, "Oporečništvo v samoupravnem socializmu: vsebina in položaj družbene kritike v Sloveniji, 19721980” (doktorska disertacija, Univerza na Primorskem, 2013).

34 Cf. Taras Kermauner, “Epilog ali nov začetek?,” Borec 48, No. 551-552 (1996): 246. 
Among them, those who dealt with political issues came to the forefront. According to party ideologists, they were by no means true Marxists. The attention of the leaders in the country was increasingly directed to the new generation raised in the new Yugoslavia, which was more indifferent to pre-war predicaments and very sensitive to deviations in post-war reality. The Slovenian Party leadership started considering the possibility that the young generation of intellectuals could be seen as a new type of opposition in 1957, one year after the political turmoil in Hungary and Poland. The main cultural ideologist of the Communist Party of Slovenia, Boris Ziherl, reported to the top leaders of the League of Communists of Slovenia that the events had also had a great influence on intellectuals in Yugoslavia and that the leaders were not particularly enthusiastic about the direction of the controversy: "Not only in Slovenia, but also elsewhere, cultural workers express the opinion that it would be necessary to revise the points on the leading role of the working class in the process of building socialism and in today's social development, as recent events have shown that the leading factor in this regard are intellectuals, especially writers. This doubt was also expressed in interviews with a delegation of Polish writers whom our writers first asked how they were preparing the October events, and further in discussions regarding the new League of Communists of Yugoslavia programme." ${ }^{35}$

The fear of denying the relevant fundamental principles on which the communist authorities were based was more and more present. These words reflected the thought that the avant-garde should no longer be based on the working class or the party that was supposed to be its personification, but on intellectuals. Such a view of the social involvement of the young generation of intellectuals was not limited to narrow-minded ideologists, such as Boris Ziherl, but was also adopted by political pragmatists, such as Boris Kraigher. In light of the scandal with the Revija 57 magazine, he did not agree with the assessment that the Revija 57 team did not have a political concept and that the concept was not the driving force of their operation. The basis for his opinion was that "these people sometimes react inappropriately to certain political measures, which means that it is then truly necessary to prevent the tendencies that led the Hungarian revolution to become a counter-revolution from becoming a reality in Slovenia as well". Due to a quite strong sense of fear that things might (in the future) go beyond that which was allowed, the Prime Minister of the Republic of Slovenia warned that even the good thoughts that grow in the wrong garden could trigger unfavourable consequences because "the Hungarian anti-Stalinist campaign brought the struggle directly into the arms of counter-revolution, although I do not agree with the way the Russians responded to this". In the political glossary of terms used by the leading communists, Kraigher said that good ideas and good initiatives could never hurt anybody. However, it would have presented a double risk if they had given incentive to those inspired by the Western-style multi-party system (in the party jargon, this was also considered a counter-revolution). It could pose a risk within the internal policy as the political monopoly of the ruling party could crumble, and

35 SI AS 1589, IK, t. e. 7, Minutes of the Executive Committee CK ZKS, 14 May, 1957, 6, 7. 
the risk within the foreign policy if the tension with the Soviet Union would increase and lead to an unpredictable outcome. The uprisings against the communist authorities in Poland and Hungary of 1956 were therefore a warning to the highest-ranking political leaders that it was better to react more quickly and prevent actions that they considered extremely political. According to Kraigher's estimates, "after the events in those countries, some people in Slovenia found courage when they saw that something can indeed be done, and therefore they are taking certain steps in this direction". Kraigher also remarked that it was perfectly clear to him that those who would think about such moves are no Edvard Kocbek, although Kocbek maintained contacts with people whose names had been recorded in police files. When he thought about the people for whom it would be a mistake to "give them the freedom to act in the name of the freedom of cultural engagement and in the name of democracy", he said that "this completely applies to that guy Pučnik". His articles and his defence for the right of workers to strike were everything that the leading Communists did not want to tolerate in their home yard. ${ }^{36}$

The Slovenian political leadership thus considered the younger generation of intellectuals in a purely political context, analysed its work using political vocabulary, and ultimately also began to deem it as a political problem. In the 1958 Annual Report of the Ministry of the Interior, i.e. at the time of the cancellation of Revija 57, and during preparations for the process against Pučnik, it was clearly recorded for the first time that the old pre-war opposition was no longer the main threat, but that the threat was now coming from elsewhere: "Regarding the hostile propaganda activities of the remnants of bourgeois parties, it is important to emphasize that this propaganda was mainly limited to various discussions and comments, i.e. that there were no organized forms of hostile activity among them, but that the problem is posed by young intellectuals who do not agree with the socialist system in our country." ${ }^{37}$

This younger generation quite unanimously defended the view that every individual has the right to express their opinion. However, during talks with politicians and in interrogations conducted by investigators, they denied the suspicions and allegations that this was just a step towards establishing an organization aimed at destroying the existing social order. The ruling circles had a completely different opinion. In a special report drawn up by the State Security Directorate during the affair surrounding Revija 57 for the Slovenian political leaders, the young generation of intellectuals was for the first time seen as potential opposition: "Together with those who are like-minded, they are trying to create an opinion that they are being persecuted as opposition, but constructive and progressive opposition, which is persecuted precisely for this reason by the government. However, by doing so, the government showed it was no longer progressive." ${ }^{38}$

36 SI AS 537, t. e. 27, Seja predsedstva SZDLS, 6 November, 1958, 52, 53.

37 SI AS 1931, A-13-O, Letno poročilo za leto 1958, 3, 4.

38 SI AS 1589, IK, t. e. 12, Naši nadaljnji ukrepi in rezultati preiskave proti skupini Revije 57, 4. 


\section{Sources and Literature}

\section{Archival Sources:}

- SI AS, Arhiv Republike Slovenije:

- SI AS 537 - Republiška konferenca Socialistične zveze delovnega ljudstva Slovenije.

- SI AS 1589 - Centralni komite Zveze komunistov Slovenije.

- SI AS 1799 - Centralni komite Ljudske mladine Slovenije.

- SI AS 1931 - Republiški sekretariat za notranje zadeve Socialistične republike Slovenije.

- SI AS 2027 - Društvo slovenskih pisateljev.

\section{Literature:}

- Božič, Peter. „Moja prva srečanja s Pučnikom“. In: Lorenci, Janko. Jože Pučnik. Ljubljana: Emonica, 1990, 88-93.

- Gabrič, Aleš. Socialistična kulturna revolucija: slovenska kulturna politika 1953 - 1962. Ljubljana: Cankarjeva založba, 1995.

- Kermauner, Taras. “Epilog ali nov začetek?”” Borec 48, No. 551-552 (1996): 241-52.

- Klabus, Vital. "Pričevanje o Reviji 57 in Perspektivah.” Borec 48, No. 551-552 (1996): 111-36.

- Kos, Janko. Ideologi in oporečniki: spominjanja. Ljubljana: Znanstvena založba Filozofske fakultete, Beletrina, 2015.

- Kos, Janko. Umetniki in meščani: spominjanja. Ljubljana: Beletrina, 2015.

- Lorenci, Janko. Jože Pučnik. Ljubljana: Emonica, 1990.

- Pesek, Rosvita. Pučnik. Celovec: Mohorjeva, 2013.

- Pučnik, Jože. Članki in spomini 1957-1985. Maribor: Obzorja, 1986.

- Ramšak, Jure. "Oporečništvo v samoupravnem socializmu: vsebina in položaj družbene kritike v Sloveniji, 1972-1980.” Doktorska disertacija, Univerza na Primorskem, 2013.

- Režek, Mateja. “Ideološko ozadje ukinitve Revije 57.” Nova revija 13, No. 151-152 (1994): 194206.

- Režek, Mateja. Med resničnostjo in iluzijo: slovenska in jugoslovanska politika v desetletju po sporu z Informbirojem: (1948-1958). Ljubljana: Modrijan, 2005. 


\section{Aleš Gabrič}

\section{JOŽE PUČNIK NA POTI DO DISIDENTA}

\section{POVZETEK}

Med slovenskimi političnimi zaporniki v času komunističnega režima je Jože Pučnik specifičen primer. Čeprav je sodeloval s številnimi drugimi intelektualci pri ustvarjanju podobe različnih revij, je s svojo kritično ostjo in nato posledično usodo političnega preganjanca predstavljal poseben primer.

Med sodelavci Revije 57, s katerimi je oblast obračunala ob koncu petdesetih let, je izstopal že po tem, da je že imel mesto v policijskem dosjeju. Leta 1951 je namreč sodeloval v reviji mariborskih srednješolcev Iskanja, čemur so sledila zaslišanja sodelavcev revije in grožnje $z$ onemogočanjem nadaljnjega šolanja. Po vpisu na Filozofsko fakulteto $v$ Ljubljani je bil agilen $v$ Zvezi študentov in $v$ javnih razpravah, ki so ga približali krogu Revije 57. Za časopis je napisal več prispevkov o tedanjih domačih družbenih razmerah. V kritičnosti Pučnik ni bil izjema, toda njegove besede so bile običajno zelo neposredne, lahko razumljive, medtem ko je bilo pri člankih nekaterih drugih piscev treba brati tudi med vrsticami. Družbena angažiranost je Pučnika v začetku leta 1958 pripeljala tudi do vstopa $\mathrm{v}$ Zvezo komunistov, kar je naletelo na burne odzive med sodelavci Revije 57, ki so posumili o vzrokih, ki so Pučnika vodili do takšne odločitve.

V Reviji 57 je v letih 1957 in 1958 Pučnik objavil več kritičnih člankov o aktualnih družbenih in političnih razmerah. Najbolj pa je razburkal stališča sodelavcev in politikov s člankom, $v$ katerem je analiziral razhajanja med idejnimi postavkami vladajoče elite in stvarnostjo ter med miselnostjo in delom komunistov pred dvema desetletjema, ko so še bili v ilegali, in po vojni, ko so se utrdili na oblasti. Oblast je v sklopu širšega obračuna s humanistično inteligenco ob koncu petdesetih let na seznam škodljivih zadev uvrstila tudi krog Revije 57. Ker poskusi mehkega utišanja besed mlajše intelektualne generacije niso uspeli, je oblast posegla po ostrejših metodah. Ob koncu leta 1958 in v začetku 1959 je bila Revija 57 večkrat tarča kritik vodilnih politikov, tema številnih sej visokih organov, očitkov, da gre za skupino mlajših intelektualcev, ki je snovala ilegalno sovražno organizacijo, širila protidržavno propagando in đilasovstvo, pozivala delavce k štrajku, vse skupaj pa je spremljala močna medijska gonja proti reviji. Višek obračuna pa je bil marca 1959 sodni proces proti Jožetu Pučniku, na katerem je bil ta obsojen na devet let zapora. Ostrina obračuna je bila presenetljiva za tedanje slovenske politične razmere. Pogled $\mathrm{v}$ zakulisje dogajanj $\mathrm{v}$ krogih najpomembnejših slovenskih oblastnih krogov pa pokaže, da je bil ta posledica ocen, v katerih je Uprava državne varnosti mlajšo intelektualno generacijo prvič ocenila kot možno potencialno opozicijo in jo namesto stare garde politikov postavila na prvo mesto med tistimi, ki so jih ocenjevali kot potencialne organizatorje opozicije. 